\title{
Trail analysis under multicollinearity of Nopalea cochenillifera in annual and biennial harvest
}

\section{Análise de trilha sob multicolinearidade de Nopalea cochenillifera na colheita anual e bienal}

Anderson Samuel Silva

Universidade Federal da Paraíba

E-mail: andersontacaratu@hotmail.com

OrcID: https://orcid.org/0000-0001-8495-0078

Edson Mauro Santos

Universidade Federal da Paraíba

E-mail: edsonzootecnista@yahoo.com.br

OrcID: https://orcid.org/0000-0003-2832-6603

João Paulo de Farias Ramos

Universidade Federal da Paraíba

E-mail: jpemepapb@yahoo.com.br

OrclD: https://orcid.org/0000-0001-6159-5026

Kilmer Oliveira Soares

Universidade Federal da Paraíba

E-mail: Kilmerzootec2010@hotmail.com

OrcID:https://orcid.org/0000-0001-8893-7225

Raniere de Sá Paulino

Universidade Federal da Paraíba

E-mail: ranierepaulino@hotmail.com

OrcID: https://orcid.org/0000-0002-3830-9076

Gabriel Ferreira de Lima Cruz Universidade Federal da Paraíba

E-mail: g ferreira dm@hotmail.com

OrcID: https://orcid.org/0000-0001-8977-1765

\begin{abstract}
Forage cactus is widely cultivated in environments with low rainfall, due to its adaptability to the climate and richness in water and carbohydrates for ruminants. Knowing the morphology of these plants and their responses to management practices through biometric data can be used to estimate their quality and productivity. Thus, the study aimed to evaluate, through trail analysis under multicollinearity, the direct and indirect effects of two basic variables of productive yield between the annual and biennial Palmepa-PB01 forage cactus variety variables. The experiment was carried out in a randomized block design, with two treatments: annual and biennial harvest frequency; and three replications each one. The plants were spaced $1.0 \mathrm{~m} \times 0.50 \mathrm{~m}$ for cultivation, to achieve plant density of 20,000 plants ha ${ }^{-1}$. For the establishment of the cactus, a cladode per pit were buried $2 / 3$ of the seedling in the soil, in a vertical position during the final third of the dry period. In 4 plants selected in the plot, their height $(\mathrm{PH})$, plant width $(\mathrm{PW})$ and cladode area index (CAI) were measured. The analysis of the trail under multicollinearity was carried out and corrected with the value of $\mathrm{K}$ to 0.1002 between the variables response of green matter (GMY) and dry matter yield (DMY) and the explanatory variables: $\mathrm{PH}, \mathrm{PW}$ and CAl. The coefficient of determination of the trail analysis model $\left(\mathrm{R}^{2}\right)$ explains for the annual and biennial harvest 96.40 and $92.25 \%$ of variation in basic variable GMY, 96.44 and $92.25 \%$ for SMP. The characters PH, PW of the plant and CAI alone do not explain the variations of GMY and DMY through the multicollinearity trail analysis test, and their relationships vary according to the annual and biennial harvest of the forage cactus.
\end{abstract}

Keywords: Characters. Explanatory variable. Frequency of collection. 
Resumo: A palma forrageira é bastante cultivada em ambientes com baixo índice pluviométrico, pela sua adaptabilidade ao clima e riqueza em água e carboidratos para os ruminantes. Conhecer a morfologia destas plantas e suas respostas as práticas de manejo através de dados biométricos, podem ser usadas na estimativa da sua qualidade e produtividade. Desta forma, objetivo deste estudo foi avaliar, através da análise de trilha sob multicolinearidade, os efeitos diretos e indiretos de duas variáveis básicas do rendimento produtivo entre as variáveis explicativas anual e bienal da palma forrageira, variedade Palmepa-PB1. O experimento seguiu o delineamento em blocos casualizados, com dois tratamentos: frequência de colheita anual e bienal do segundo ciclo da palma forrageira; e três repetições cada. As plantas foram espaçadas 1,0 $\mathrm{m} \times 050 \mathrm{~m}$ para o cultivo, com uma densidade de plantio de 20.000 plantas ha-1. Para o estabelecimento da palma, foi plantado um cladodío por cova na posição vertical no terço da estação seca, 2/3 das mudas foram enterradas no solo. Em 4 plantas selecionadas na parcela, foram medidos a altura (AP), largura da planta (LP) e índice de área do cladódio (IAC). A análise da trilha sob multicolinearidade foi realizada e corrigida com o valor de $\mathrm{K}$ a 0,1002 entre as variáveis resposta da produção de matéria verde (PMV) e matéria seca (PMS) e as variáveis explicativas: AP, LP e IAC. O coeficiente de determinação do modelo de análise de trilha (R2) explica para a safra anual e bienal 96,40 e 92,25\% da variação da variável básica PMV, 96,44 e 92,25\% para SMP. Os caracteres AP, LP da planta e IAC por si só não explicam as variações de PMV e PMS por meio do teste de análise de trilha de multicolinearidade, e suas relações variam de acordo com a colheita anual e bienal da palma forrageira.

Palavras-chave: Caracteres. Frequência de colheita. Variável explicativa.

Data de recebimento: 04/05/2020

Data de aprovação: 01/03/2021 DOI: https://doi.org/10.30612/agrarian.v14i52.11853

\section{Introduction}

The forage cactus is cultivated all over the world, and has several purposes, among them, stands out the use for forage production (Bayar et al., 2018; Volpe et al., 2018). Thus, the forage cactus plays an important role in the semiarid regions of Brazil, due to diversifications of use, supplying the need for fodder in periods of prolonged drought. It has high productivity of fresh and dry matter per hectare, which contributes to its cultivation by small farmers and ranchers from regions with lower annual rainfall in rainfed systems.

There are few studies in the literature that relate morphological aspects with cactus productivity through trail analysis, which can infer about the plant response to the management adopted in rainfed system. Thus, (Sales et al., 2006) affirm that morphological knowledge is important to intend significant gains and that the responses of the correct management practice can provide an estimation of cactus quality through biometric information.

The magnitude of the simple correlation can erroneously provide wrong results, overestimating the data, because, correlations with high degree between characters is the result of the effect on the same or groups of characters. In this way, (Wright, 1921), aiming to interpret and better understand these relationships, proposed the unfolding of the correlations through path analysis estimating direct and indirect effects of independent variables (explanatory) on the response variable (basic).

In estimating the direct and indirect effects of different independent variables on the response variable, it is necessary to obtain the path coefficient. Thus, these coefficients can be affected by problems of multicollinearity effects between variables to be studied. This multicollinearity occurs when there are high correlations between the independent and explanatory variables or the combination between them making them unreliable (Ferrari, 1989).

In order to attenuate the effect of multicollinearity, there is the method proposed by (Carvalho, 1995) called ridge path analysis, without discarding the variables with a high degree of collinearity, and, in addition to evaluating all the variables, it is possible to perform only an analysis. This is possible due to the modification of the normal equations, through the constant $\mathrm{K}$ of the matrix diagonal. According to (Carvalho, 1995), the value of " $\mathrm{k}$ " should be as small as possible, thus stabilizing the path coefficients associated with the explanatory 
variables and the response variables. Thus, it is possible to perform path analysis studies under multicollinearity with all variables.

In view of this context, this study aimed to evaluate, through the Path analysis under multicollinearity, the direct and indirect effects of two variables (productive) among the explanatory responses (morphological) variables of the Palmepa-PB01 forage cactus Variety.

\section{Material and Methods}

The study was carried out under field conditions at the experimental station Benjamim Maranhão in Tacima-PB, Brazil, at the State Agricultural Research Company of Paraíba (Empresa Estadual de Pesquisa Agropecuária da Paraíba - EMEPA) located in the Agreste Mesoregion of the Paraíba. The climate is tropical semiarid, with summer rains. The average annual rainfall is $626 \mathrm{~mm}$, average annual temperature of $24.8^{\circ} \mathrm{C}$, with BSh climate according to the Koppen's classification, altitude of $166 \mathrm{~m}$ above sea level. The geographic coordinates are $6^{\circ} 29^{\prime} 16^{\prime \prime} \mathrm{S}, 35^{\circ} 38^{\prime} 13^{\prime \prime} \mathrm{W}$, where it was conducted under rainfed system.

The experiment followed a randomized block design (RBD) with three replications, with two treatments: annual and biennial harvest frequency. The biometric and productive measurements were performed in December 2018, in second production cycle of the cactus crop.

The Palmepa-PB01 (Nopalea cochinilifera Salm Dyck) variety was cultivated in simple rows. The plants were spaced by $1.0 \mathrm{~m} \times 0.50 \mathrm{~m}$ for cultivation, and plots of $28 \mathrm{~m}^{2}$ each, being $20 \mathrm{~m}^{2}$ the useful area of the plot and eight $\mathrm{m}^{2}$ of surrounding, with a planting density of 20,000 plants ha-1.

Soil samples were collected from the experimental area in the $0-20 \mathrm{~cm}$ depth layer, to evaluate the chemical characteristics at the beginning of the experiment. Next, two mineral fertilizations were made according to the recommendation manual for Forage cactus (Opuntia sp. and Nopalea sp.), described by (Santos et al., 2008) proposed for the state of Pernambuco. The soil is classified as a solodic Eutrophic Haplic Planosol (SXe) according to the Santos et al. (2013). Where the chemical attributes were: $\mathrm{pH}=5.1, \mathrm{P}=73.95$

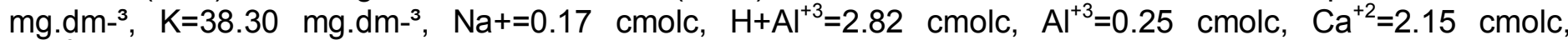
$\mathrm{Mg}^{+2}=1.92$ cmolc, $\mathrm{SB}=4.34, \mathrm{MO}=10.27 \mathrm{~g} \cdot \mathrm{kg}-1$ e $\mathrm{CEC}=7.16$.

The implantation of the Forage cactus was carried out before the beginning of the rainy season, in order to avoid high levels of water in the soil, preventing losses of the cladodes by rotting. The cladodes were positioned vertically on the ground, with about $2 / 3$ of it covered by the ground. When necessary, manual weeding was performed to control spontaneous plants.

For the biometric variables, 4 plants of the useful area of the plot were chosen. In plants, height $(\mathrm{PH})$ and Width (PW) were analyzed. The height was measured from the surface of the soil to the highest cladode, while the width was obtained by using its two largest dimensions as a reference, and both variables were measured with the aid of a tape measure. Then, the plants were cut, preserving the primary cladode and identified according to the numbering of the plant. Subsequently, they were weighed individually in the field, to avoid water loss, to determine the green matter yield (GMY).

Dry matter content (DM) was determined through the pre-drying in a kiln at $65{ }^{\circ} \mathrm{C}$ to constant weight (air-dried), then ground in a sieve of $2 \mathrm{~mm}$ and dried in a kiln at $105^{\circ} \mathrm{C}$ for 16 hours (oven-dried). Dry matter yield (DMY) was determined by multiplying the GMY by the DM contents.

During the experimental period, the meteorological variables of rainfall $(\mathrm{mm})$ were monitored by means of a conventional station belonging to the State Agricultural Research Company of Paraiba (EMEPA), located 150 meters from cultivation area (Figure 1).

Pearson's correlations and multicollinearity test were previously performed, to avoid the problem of overestimation of the effects between the explanatory variables. The diagnosis considered the effect of condition number $(\mathrm{CN})$, which is the ratio between the highest and lowest self-value of the Matrix, being: $\mathrm{CN}<100$ weak multicollinearity, $100<\mathrm{CN}$ Moderate to strong and $\mathrm{CN}>1.000$ Severe, by the method described by (Toebe \& Cargnelutti Filho, 2013). The discards of variables with high multicollinearity were performed and then used the ridge path analysis.

For the ridge path analysis, the methodology proposed by (Carvalho, 1995) was used, in the modification of the equation system, by the constant $\mathrm{K}$ to the diagonal of the $\mathrm{X}^{\prime} \mathrm{X}$ matrix and obtained the path coefficients (Eq. 1).

$$
\left(X^{\prime} X+K I p\right) \theta^{*}=X^{\prime} Y
$$




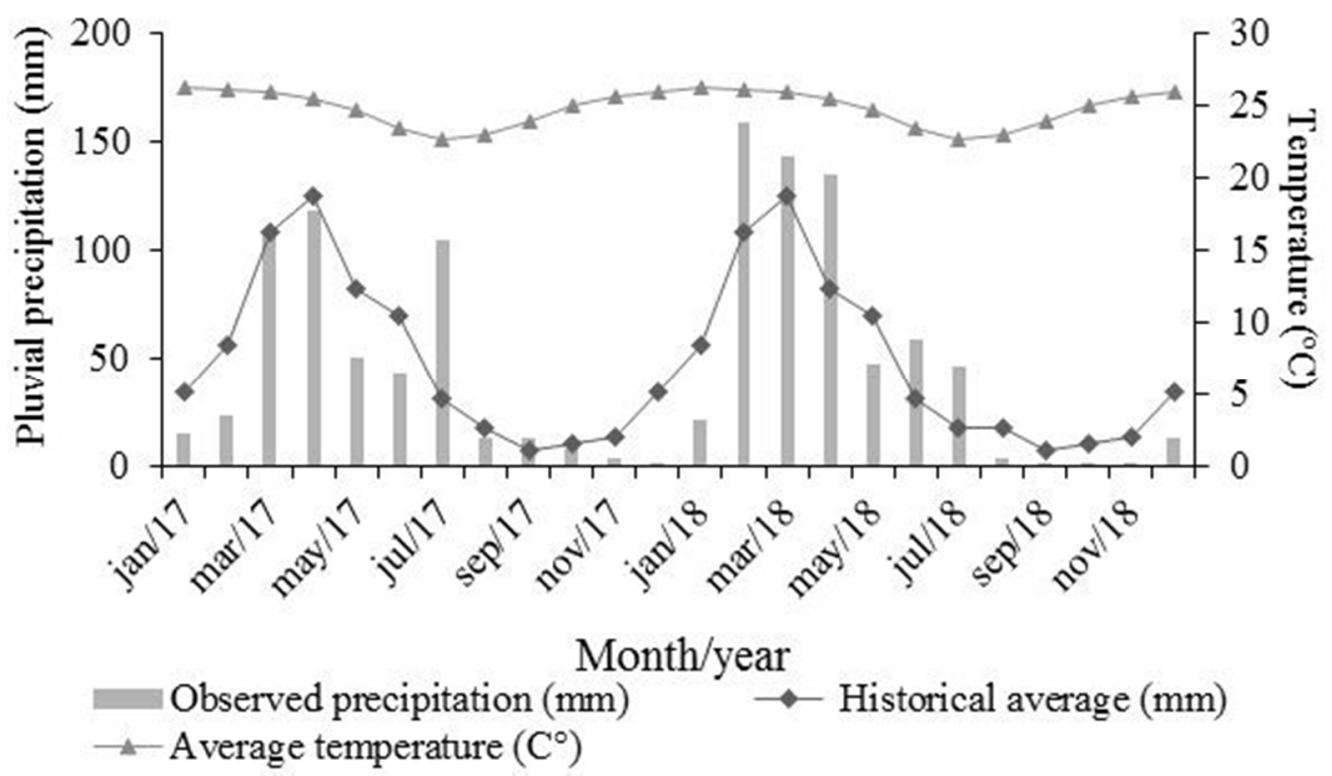

Figure 1. Pluvial precipitation in the experimental station Benjamim Maranhão (source: EMEPA), normal climatological and average monthly temperature, Tacima-PB (Source: Climatempo).

Thus, $X^{\prime} X$ is the matrix of correlations between the independent variables of the regression model, $X^{\prime} X$ is the matrix of correlations between the independent variables of the regression model; $\mathrm{K}$ is a small amount added to the diagonal elements of the $X^{\prime} X$ matrix; Ip is the identity matrix; $\theta^{*}$ is the vector of the estimators of the path coefficients; And $X^{\prime} Y$ is the matrix of correlations between the dependent variable with each variable independent of the regression model. The appropriate value for the constant $\mathrm{K}$ was determined, in this assay, by examining the ridge path analysis (Hoerl \& Kennard, 1970). The ridge path analysis was obtained by plotting the estimated parameters (path coefficients) according to the $\mathrm{K}$ values in the range of $0<\mathrm{K}<1$.

A multicollinearity path analysis was performed, corrected with the value of $\mathrm{K}$ for 0.1002 of the variables response of green and dry matter yield and the explanatory variables: plant height, plant width and cladode area index (CAI). The computational software GENES (Cruz, 2013) performed all analyses of this assay.

It determined the phenotypic correlations and the analysis of the estimated trail coefficients, unfolding the correlations of explanatory variables (production characters) on those of response (productivity) of the forage cactus.

\section{Results and Discussion}

The magnitude and direction of the direct and indirect effects of the phenotypic characteristics related to green matter yield with annual and biennial harvest are shown in table 1 . The coefficient of determination of the model of the path Analysis $\left(R^{2}\right)$ of this study explains for the annual and biennial harvest $96.40(270 \mathrm{t} / \mathrm{ha}=$ 
$27 \mathrm{t} / \mathrm{DM} / \mathrm{ha}$ ) and $92.25 \%$ (204t / ha $=26.52 \mathrm{t} / \mathrm{DM} / \mathrm{ha})$ respectively of the variation from GMY, being almost totally explained by this scheme in both frequencies of harvest.

Table 1. Estimates of the direct and indirect effects of the explanatory variables plant height, plant width and cladode area index on the production of green matter from forage cactus Palmepa-PB01 var. according to the frequency of the annual and biennial Harvest.

\begin{tabular}{|c|c|c|}
\hline Variable & Effect & Estimation \\
\hline \multicolumn{3}{|c|}{ Annual harvest } \\
\hline \multirow{4}{*}{$\mathrm{PH}$} & Direct via GMY & 0.3233 \\
\hline & Indirect via PW & 0.3293 \\
\hline & Indirect via CAI & 0.2817 \\
\hline & Total & 0.9667 \\
\hline \multirow{4}{*}{ PW } & Direct via GMY & 0.3295 \\
\hline & Indirect via PH & 0.3231 \\
\hline & Indirect via CAI & 0.2891 \\
\hline & Total & 0.9747 \\
\hline \multirow{4}{*}{ CAl } & Direct via GMY & 0.3616 \\
\hline & Indirect via PH & 0.2518 \\
\hline & Indirect via PW & 0.2634 \\
\hline & Total & 0.9134 \\
\hline$\overline{R^{2}}$ & & 0.9640 \\
\hline ERV & & 0.1895 \\
\hline \multicolumn{3}{|c|}{ Biennial harvest } \\
\hline \multirow{4}{*}{$\mathrm{PH}$} & Direct via GMY & 0.1432 \\
\hline & Indirect via PW & 0.0705 \\
\hline & Indirect via CAI & 0.6980 \\
\hline & Total & 0.9239 \\
\hline \multirow{4}{*}{ PW } & Direct via GMY & 0.0706 \\
\hline & Indirect via $\mathrm{PH}$ & 0.1431 \\
\hline & Indirect via CAI & 0.6901 \\
\hline & Total & 0.9098 \\
\hline \multirow{4}{*}{ CAI } & Direct via GMY & 0.7295 \\
\hline & Indirect via $\mathrm{PH}$ & 0.1370 \\
\hline & Indirect via PW & 0.0668 \\
\hline & Total & 0.9952 \\
\hline $\mathrm{R}^{2}$ & & 0.9225 \\
\hline ERV & & 0.2032 \\
\hline
\end{tabular}

GMY-green matter yield; PH-plant height; PW-Plant width; CAl- cladode area index; $\mathrm{R}^{2}{ }^{2}$ - Coefficient of determination; ERV-effect of residual variable.

For the annual harvest, the three evaluated characters had a positive direct effect and above the effect of the residual variable (ERV), but with a low magnitude, according to the classification of (Martins \& Domingues, 2011). This showed that the height (PH) and width (PW) of plants and the cladode area index (CAI) isolated do not explain the variation of the green matter yield (GMY), but they do explain when together.

All indirect effects were above positive ERV and low magnitude. With higher values found in $\mathrm{PH}$ via PW and vice versa on the GMY (above $r=0.3000$ ). This was expected due to height and width having a high correlation in forage cactus growth. Therefore, these morphological characteristics together can be taken into consideration when choosing more productive varieties in an annual harvest.

Silva et al. (2010) evaluating the effects between morphological characteristics of different genotypes of forage cactus on yield, found that the height and width of the plant were the most important traits in the unfolding through the path analysis, corroborating the results in the present study.

For the biennial harvest, only variable CAI had direct effect with high and positive magnitude $(r=$ 0.7295), being greater than the residual effect on the variable GMY, standing out as the main character responsible for the biomass production in this study. Only the CAI presented significant results alone. The others together presented highest total coefficient estimators, above $r=0.9000$ and positive. 
Possibly this result is associated with the cladodes age, since the biennial harvest provides wider and longer cladodes, when compared to the annual harvest, in addition to the higher number of cladodes. These variables presented a high degree of multicollinearity, therefore, discarded from the trail analysis, thus it was necessary to exclude to generate an appropriate and safe interpretation.

The CAl is a measure that provide a diagnosis of the effects used in the management on the growth of cactus crop (Oliveira Junior et al., 2009). The indirect effect of PH and PW via CAI on the GMY was also high and higher than the residual effect, reinforcing the importance of these two independent variables for the variation of yield of forage cactus.

The explanatory variables $\mathrm{PH}$ and $\mathrm{PW}$ showed positive correlations with direct and indirect effect, but with a low and lower magnitude than the residual effect. In this way, these variables do not explain the variation of the GMY alone and depends on other explanatory variables.

Montardo et al. (2003) reported that the correlations of low magnitudes between the characters are justified by the low variability of one of these traits, which can be observed for PH and PW, with direct and indirect effect, thus the trail analysis unfolds the association of variation of these variables among themselves or grouped.

In general, it was perceived that the green matter productivity result of interaction between the variety and the environment and changes according to the annual and biennial harvest frequency. Peixoto and Peixoto (2009) reported that in order to determine productive aspects and derived from intrinsic factors, morphological knowledge can give us relevant subsidies through quantitative growth data.

For the basic variable of GMY, the characters of PH and PW obtained coefficients with moderate magnitude for the direct effects in the annual harvest $(r=0.3534$ and 0.3549$)$ and biennial $(r=0.4302$ and 0.4753 respectively), positive and above the residual variable. Where the model of the path analysis, according to the coefficient of determination explained 96.44 and $92.25 \%$ for annual and biennial respectively of the variation of the basic variable of DMY (table 2).

Table 2. Estimates of the direct and indirect effects of the explanatory variables of plant height, plant width, and cladode area index on the production of dry matter yield from forage cactus Palmepa-PB01 var. according to the frequency of the annual and biennial harvest.

\begin{tabular}{|c|c|c|}
\hline Variable & Effect & Estimation \\
\hline \multicolumn{3}{|c|}{ Annual harvest } \\
\hline \multirow{3}{*}{$\mathrm{PH}$} & Direct via DMY & 0.3534 \\
\hline & Indirect via PW & 0.3547 \\
\hline & Total & 0.9787 \\
\hline \multirow{2}{*}{ PW } & Direct via DMY & 0.3549 \\
\hline & Total & 0.9850 \\
\hline \multirow{4}{*}{ CAI } & Direct via DMY & 0.3017 \\
\hline & Indirect via PH & 0.2753 \\
\hline & Indirect via PW & 0.2837 \\
\hline & Total & 0.8910 \\
\hline
\end{tabular}

Biennial harvest

$\mathrm{PH}$

Direct via DMY

0.4302

Indirect via PW

0.4752

Indirect via CAI

0.0427

Total

0.9914

Direct via DMY

0.4756

Indirect via $\mathrm{PH} \quad 0.4300$

PW

Indirect via CAI

0.0422

Total

0.9954

CAI

Direct via DMY

0.0446

Indirect via $\mathrm{PH}$

0.4117 


\begin{tabular}{lr}
\hline $\mathrm{R}^{2}$ & 0.9225 \\
\hline $\mathrm{ERV}$ & 0.2032
\end{tabular}

DMY-dry matter yield; PH-plant height; PW-plant width; CAl-Cladode area index; $\mathrm{R}^{2}$-Coefficient of determination; ERV-effect of residual variable.

About the İAC alone or in all the sets presented a direct and indirect effect of low magnitude on the DMY for the annual harvest, and below the residual variable $(0.2437)$ for the biennial harvest. This showed no influence on the variation in dry matter yield at two years of cultivation.

Leite (2009) reports that the variety Palmepa-PB01 does not present a large number of cladodes, however, the habit of semi open growth provides for the plant greater utilization of photosynthetic. Thus, influencing the CAI being perceptible in the biennial harvest due to the age of the cladodes.

The indirect influence of the $\mathrm{PH}$ is reflected in the higher magnitude of PW and vice versa on DMY, where higher plants reflect in wider plant in both crops and consequently higher dry mass yield. Corroborating the results found by (Silva et al., 2010), who found through Pearson's correlation that the plant height is more associated with DMY and that the greater the plant height, the greater its width.

The effect of PW can be justified by the age of the plant because it reflects the emission of the cladodes and the growth stage of them, which justifies the indirect effect on the $\mathrm{PH}$ and direct on the DMY in the biennial harvest with estimates above $r=0.4700$. Thus, an isolated character to determine DMY, then, should be used in association with other variables, having as direct and indirect effects as a data of great importance to assist in the selection of variables of high correlation. (Sales et al., 2003) reported that plant genetics influences morphological characteristics, but climatic conditions can also have a strong influence on PW, directly affecting dry matter production.

The water conditions were possibly not a limiting factor for the development of the forage cactus, providing an ideal environment for the plant to express its relationships between the independent and basic characters. Because even though the irregularity of rainfall, the annual average rainfall was above $560 \mathrm{~mm}$ per year.

\section{Conclusion}

The characters height and width of the plant and the cladode area index alone do not explain the variations of GMY and DMY through the multicollinearity trail analysis test, and their relationships vary according to the annual and biennial harvest of the forage cactus.

\section{References}

Bayar, N., Friji, M., Kammoun, R. (2018). Optimization of enzymatic extraction of pectin from Opuntia ficus indica cladodes after mucilage removal. Food Chemistry, v.241, p.127134.https://doi.org/10.1016/.j.foodchem.2017.08.051

Carvalho, S.P. (1995). Métodos alternativos de estimação do coeficiente de trilha e índices de seleção, sob multicolinearidade. Viçosa: Universidade Federal de Viçosa, p.163.

Climatempo. (2019). Disponível em: http://www.climatempo.com.br/climatologia/tacima-pb. Acesso em: 02/11/2019.

Cruz, C.D. (2013). GENES: A software package for analysis in experimental statistics and quantitative genetics. Acta Scientiarum, v.3, n.35, p.271-276. https://doi.org/10.4025/actasciagron.v35i3.21251

Ferrari, F. (1989). Estimadores visados para modelos de regressão em presença de multicolinearidade. Piracicaba: USP-ESALQ. 127p. https://doi.org/10.11606/T.11.2020.tde-20200111-132820

Hoerl, A.E., Kennard, R.W. (1970). Ridge regression: biased estimation for nonorthogonal problems. Technometrics, Washington, v.12, n.1, p.55-68.

Leite, M.L.M.V. Avaliação de clones de palma forrageira submetidos a adubações e sistematização de informações em propriedades do semiárido paraibano. 2009. 186 f. Tese (Doutorado em Zootecnia) - Centro de Ciências Agrárias, Universidade Federal da Paraíba, Areia, 2009.

Martins, G.A., Domingues, O. (2011). Estatística geral e aplicada. 4.ed. São Paulo: Atlas. p.662. 
Montardo, D.P., Agnol, M.D., Crusius, A.F. (2003). Análise de trilha para rendimento de sementes de trevo vermelho (Trifolium pratense L.). Revista Brasileira de Zootecnia, v.32, n.5, p.1076-1082. https://doi.org/10.1590/S1516-35982003000500007

Oliveira Junior, S., Barreiro Neto, M., Ramos, J.P.F., Leite, M.L.M.V., Brito, E.A., Nascimento, J.P. Crescimento vegetativo da palma forrageira (Opuntia fícus-indica) em função do espaçamento no Semiárido paraibano. Tecnologia \& Ciência Agropecuária, João Pessoa, v.3, n.1, p.7-12, 2009.

Peixoto, C.P., Peixoto, M.F.S.P. (2009). Dinâmica do crescimento vegetal. In: Carvalho, C. A. L.; Dantas, A. C. V. L.; Pereira, F. A. C.; Soares, A. C. F.; Melo Filho, J. F.; Oliveira, G. J. C. (Org.). Tópicos em Ciências Agrárias. Universidade Federal do Recôncavo da Bahia. v.8, p. 39-53.

Sales, A.T., Andrade, A.P., Silva, D.S. (2003). Taxa de crescimento relativo de palma forrageira (Nopalea cochenillifera Salm-Dyck). Pesquisa Agropecuária Brasileira, v.38, n.1, p.340-346.

Sales, A.T., Andrade, A.P., Silva, D.S. (2006). Potencial de adaptação de variedades de palma forrageira (opuntia ficus-indica e nopalea cochenilifera) no Cariri Paraibano. In: IV Congresso Nordestino de Produção Animal. Petrolina - PE. Petrolina - PE: SNPA, p. 434-438.

Sampaio, E.V.S., Menezes, R.S.C., Salcedo, I.H., Souza, F.J. (2005). Produtividade de palma em propriedades rurais. In: Menezes, R.S.C.; Simões, D.A.; Sampaio, E.V.S.B (Org.). A palma no Nordeste do Brasil: conhecimento atual e novas perspectivas de uso. UFPE: Recife, v1, p. 231-242.

Santos, D.C., Lira, M.A., Dubeux Júnior, J.C.B., Santos, M.V.F., Mello, A.C.L. (2008). Palma forrageira. In: Cavalcanti, F. J. A. (Org.). Recomendações de adubação para o estado de Pernambuco: $2^{a}$ aproximação. 3.ed. Recife: Instituto Agronômico de Pernambuco - IPA. p.178.

Santos, H.G., Jacomine, P.K.T., Anjos, L.H.C., Oliveira, V.A., Oliveira, J.B., Coelho, M.R., Lumbreras, J.F., Cunha, T.J.F. (2013). Sistema Brasileiro de Classificação de Solos (3ª ed.). Rio de Janeiro: Embrapa Solos

Silva, N.G.M., Lira, M.A., Santos, M.V.F., Dubeux Júnior, J.C.B., Mello, A.C.L., Silva, M.C. (2010). Relação entre características morfológicas e produtivas de clones de palma forrageira. Revista Brasileira de Zootecnia, v.39, p. 2389-2397.https://doi.org/10.1590/S1516-35982010001100011

Toebe, M., Cargnelutti Filho, A. (2013). Não normalidade multivariada multicolinearidade na análise de trilha em milho. Pesquisa Agropecuária Brasileira, v.48, n.5, p. 466-477. https://doi.org/10.1590/S0100204X2013000500002

Toebe, M.; Cargnelutti Filho, A. (2013). Multicollinearity in path analysis of maize (Zea mays L.). Journal of Cereal Science, v.57, p.453-462. https://doi.org/10.1016/j.jcs.2013.01.014

Volpe, M., Goldfarb, J.L., Fiori, L. (2018). Hydrothermal carbonization of Opuntia ficus-indica cladodes: Role of process parameters on hydrochar properties. Bioresource Technology, v.247, p. 310-318. https://doi.org/10.1016/i.biortech.2017.09.072

Wright, S. (1921). Correlation and causation. Journal of Agricultural Research, v.20, p.557-585. 